\title{
EFFECT OF SILVER NANOPARTICLES ON HEALING OF THIRD-DEGREE BURNS INFECTED WITH PSEUDOMONAS AERUGINOSA IN LABORATORY MICE
}

\author{
Mukhallad Abdul Kareem Ramadhan ${ }^{1}$, Abbas Najee Balasm¹, \\ Sanaa Basher Kadhem² ${ }^{2}$ Haider Faleh Al-Saedi ${ }^{3}$ \\ ${ }^{1}$ Department of Pathology, College of Medicine, University of Misan, Misan, Iraq \\ ${ }^{2}$ Department of Microbiology, College of Medicine, University of Misan, Misan, Iraq \\ ${ }^{3}$ Department of Pharmacology and Toxicology, College of Pharmacy, \\ University of Al-Ameed, Karbala, Iraq
}

Received 16 February 2020; Received in revised form 24 October 2020; Accepted 6 November 2020

\begin{abstract}
The treatment of full-thickness skin burn using nanomaterials is promising as a medical application reducing the risk of infection and severe dermal scarring. Therefore, this study aims to evaluate the effectiveness of nanomaterials, particularly $3 \%$ silver nanoparticles containing ointment ( $3 \% \mathrm{SNO})$, on the full-thickness skin burn of laboratory mice. A total number of 36 male mice were used, equally divided into three groups: negative control (not burned and not treated); positive control $(+\mathrm{ve})$ (burned and treated with castor oil and white petroleum jelly); and SNO-treated group (burned and treated with $3 \%$ SNO). The skin of the animals' back was shaved. A $2 \times 0.5 \mathrm{~cm}$ metal plate was heated on a burner to burn the skin of the animals of positive control and SNO-treated groups. Pseudomonas aeruginosa bacterial suspension was applied to the burnt area. The application of SNO, as well as the mixture of white petroleum jelly and castor oil, was started after 6 hours of inducing burns and continued for 14 days (three times daily) in the respected groups. The SNO-treated group showed accelerated healing within 14 days demonstrated by re-epithelialization of the epidermal layer and proliferation of the fibroblasts in the dermal layer. Less healing evidence was observed in the +ve control group in the same period. In conclusion, to our knowledge, this is the first study that uses a 3\% SNO formula and has found that it has a promising impact on the treatment of infected skin burns.
\end{abstract}

Key words: silver nanoparticles, skin burns, silver ointment, skin healing, infected burns

\section{INTRODUCTION}

According to its chemical structure, nanoparticles are described as clusters of atoms that range from 1 to $100 \mathrm{~nm}$ in diameter (1). Nanoparticlebased therapies in wound care are relatively new compared to traditional biomaterials that have been used for a long time (2). Silver-nanoparticles

Corresponding author: Dr. Mukhallad Abdul Kareem Ramadhan, $\mathrm{PhD}$ E-mail address: mukalad.mcm@uomisan.edu.iq Present address: Department of Pathology, College of Medicine, University of Misan, Misan, Iraq

Phone: +964 7705502586

Copyright: (C) 2020 Ramadhan M.A.K. This is an open-access article published under the terms of the Creative Commons Attribution License which permits unrestricted use, distribution, and reproduction in any medium, provided the original author and source are credited. Competing Interests: The authors have declared that no competing interests exist.

Available Online First: 11 December 2020

Published on: 15 March 2021

https://doi.org/10.2478/macvetrev-2020-0032
(SNPs) (Nano-crystals) have been used effectively in the treatment of wounds in both emergency and cosmetic wards, for their effective antimicrobial activities, and ability in cytokine modulation and inhibition of inflammation $(3,4)$. Therefore, they are also indicated for other skin injuries including small wounds, laceration wounds, abrasion wounds, and first and second-degree burns.

Historically, silver nitrate was used for the treatment of ulcers (5). However, silver usage was reduced during the World War II when antibiotics were discovered and widely replaced the ancient schemes of antimicrobial approaches $(6,7)$. Toward the end of the $20^{\text {th }}$ century, the usage of silver for the treatment of wounds emerged again and silver nanoparticle products became commercially available and were frequently reported as being safe $(8,9)$. It was reported that fibroblasts and 
keratinocytes had not been affected by the use of nano-silver $(10,11)$.

Burns are a type of skin wounds classified into the following categories: 1 . first degree, involving the epidermal layer; 2 . second degree, involving the papillary layer and possibly the reticular layer of the dermis (12); 3. third degree, including the epidermal layer and subcutaneous tissues (13); 4. fourth degree, including damage to the full thickness of the skin and subcutaneous tissue in addition to the underlying supportive tissues along with the muscles, tendons, and ligaments (14).

Skin wound healing includes overlapping patterns of several events including coagulation, inflammation, proliferation, matrix, and tissue remodeling. It is always expected for the wound to heal within minimum time, with less scarring, and paramount functional restoration of the injured site (15).

One of the most important challenges in the treatment of burns is the infection because it delays the healing process by extending the inflammatory phase. Moreover, the presence of tissue debris at the site of the burn together with consumption of the body protein and immunosuppression may encourage bacterial growth $(16,17)$. Recent evidence suggests that SNP have potent antiinflammatory effects $(18,19,20)$ and assist in the acceleration of wound healing $(21,22)$.

Hence, the present study aimed to achieve treatment of third-degree burns by using pure SNP ointment (SNO).

\section{MATERIAL AND METHODS}

\section{Animal experiments}

The study was conducted in the Medical College - University of Misan - Misan - Iraq. The skin burning procedure in the experimental animals (mice) was carried out according to the protocols approved by the bioethical committee (No. 7/19, 2018) which follows the guidelines of the Iraqi Ministry of Higher Education and Scientific Research for laboratory animal care and use.

Thirty-six (seven weeks old) laboratory male mice weighing 20-30 g were divided equally into three groups $(n=12)$. They were grouped as: negative control (not burned and not treated), positive control (burned and treated with castor oil, and white petroleum jelly), and 3\% SNO treated group (burned and treated with prepared ointment). Animals of each group were accommodated in a single cage for one week to achieve acclimatization, with free access to water and food. Animals were fed with standard commercial pellets. The accommodation was under controlled environmental conditions (temperature $23 \pm 2{ }^{\circ} \mathrm{C}$, humidity $55 \pm 15 \%$, lighting regimen of 12-h light: 12-h dark).

Preparation of $3 \%$ silver nanoparticles ointment (3\% SNO)

A homogenized ointment was prepared by mixing $1.5 \mathrm{~g}$ of silver nano-powder (Areej Al-Furat Company, Baghdad, Iraq) with $3 \mathrm{ml}$ of castor oil (Turkey) and added to $45.5 \mathrm{~g}$ white petroleum jelly (Unilever, UK) (23). A plastic spatula fixed to INGCO cordless drill was used to get a homogenized mixture. The maximum speed of the drill was 750 RPM according to the manufacturer's instruction. The homogeneity of the ointment was evaluated by a scanning electron microscope (JEOL 7600, USA) (24). The $\mathrm{pH}$ of the $3 \% \mathrm{SNO}$ was measured with a $\mathrm{pH}$-meter. One gram of ointment was taken and dissolved in distilled water at room temperature and stored for two hours. $\mathrm{pH}$-meter was calibrated using 4 and $10 \mathrm{pH}$ standards before use. The $\mathrm{pH}$ of the ointment was measured before each use (23).

\section{Spreadability}

The technique described by Patel et al. (25) was employed to test the spreadability. Shortly explained, $1 \mathrm{~g}$ of $3 \% \mathrm{SNO}$ was placed on a glass slide which was covered by another slide, and a weight of $100 \mathrm{~g}$ was placed upon the upper slide for 5 minutes to evacuate the entrapped air and to form a thin layer of ointment between slides. The weight was removed and the excess material was scraped off. The weight was added again and the lower slide was held firmly while the upper slide was moving gradually. The time taken for the upper slide to separate away from the lower was recorded. This process was repeated three times and the average time was recorded.

\section{Antibacterial activity of the $3 \%$ SNO}

The antimicrobial activity of the 3\% SNO against multidrug-resistant Pseudomonas aeruginosa was evaluated by agar diffusion technique on the Mueller Hinton agar. The agar was prepared by following the manufacturer's specifications. The bacterial isolate was cultured by the spreading method. The ointment was seeded in a bore which was previously made in the agar by using an $8 \mathrm{~mm}$ diameter sterile Cork borer. The 
dishes were allowed to stand at room temperature for 15 minutes to allow pre-diffusion and then were incubated at $37^{\circ} \mathrm{C}$ overnight. Bacterial growth was noted and the inhibition zone was measured (26) and compared with the inhibition zones induced by the following antibiotics: penicillin, streptomycin, cefepime, amoxicillin, gentamycin, amikacin, levofloxacin, and imipenem.

\section{Induction of full-thickness skin burn}

Animals from the positive control and treated groups were anesthetized by intra-peritoneal injection of xylazine and ketamine (Alfasan, Woerden, Holland) in doses of 5, $100 \mathrm{mg} / \mathrm{kg}$ b.w., respectively (27). The mice's skin was shaved in the back region, and a full-thickness burn wound was induced with a metal plate $(2 \times 0.5 \mathrm{~cm})$ heated to $100^{\circ} \mathrm{C}$. All animals were injected with $0.5 \mathrm{ml}$ normal saline intraperitoneally to prevent dehydration. The burns were left uncovered without dressing throughout the study (28).

\section{Determination of $L D_{50}$ and infective dose}

Six groups of laboratory mice $(n=4)$ were used for a pilot study to determine the $\mathrm{LD}_{50}$ and infective dose. The first group served as negative control while the other groups were injected intraperitoneally with suspensions of Pseudomonas aeruginosa in concentrations of $10^{10}, 10^{9}, 10^{8}, 10^{7}$, $10^{6} \mathrm{CFU}$, respectively. Animals were observed for 10 days and the live and dead animals in each group were recorded to calculate the $\mathrm{LD}_{50}$. The infective dose was determined according to the equation of the $\mathrm{LD}_{50}$ (29). Proportional distance $=$ above $50 \%-50 \%$ above $50 \%$ - below $50 \%$.

\section{Treatment of the burns}

Three concentrations of SNO $(1 \%, 3 \%$ and $5 \%$ ) were assessed for effectiveness on skin burns healing. The $1 \%$ SNO showed little impact in the treatment of skin burns, the 3\% SNO showed sufficient benefit on skin burns with no side effects, and the 5\% SNO gave superior results but induced black pigmentations on the skin which was considered as unfavorable. Therefore, 3\% SNO was used in the present study for the treatment of skin burns in experimental mice.

The 3\% SNO was applied on the burnt skin in the animals of the treated group following 6 hours after burning. This treatment was repeated on every 8 hours for 14 days (23).

\section{Animals' sacrifice and tissue harvesting}

Four mice of each group were sacrificed on the $3^{\text {rd }}, 7^{\text {th }}$ and $14^{\text {th }}-$ day post burning of the skin, by deep anesthesia with chloroform (30). The site of the burns was grossly inspected to confirm the changes and it was measured by Vernier calipers. An area of $2 \mathrm{~cm}^{2}$ of the skin, including the burned area, was harvested and placed in $10 \%$ neutral buffered formalin for histopathological study.

\section{Histopathology}

The tissues were processed by ascending series of alcohol concentrations starting from 70 to $100 \%$, cleared by xylene, and embedded with paraffin. Paraffin blocks were made and sectioned by microtome to $5 \mu \mathrm{m}$ sections. Sections were stained with hematoxylin and eosin and inspected by a light microscope (30).

\section{Statistical analysis}

Data were statistically analyzed by SPSS software statistical program. The data were expressed as the means and standard deviation. T-test was used. Values of $\mathrm{p}<0.05$ were considered as statistically significant.

\section{RESULTS}

\section{Homogeneity and spreadability of SNO}

Scanning electron microscopic study showed the homogenized distribution of the SNPs within the ointment (Fig. 1). The SNPs size in the ointment was confirmed as $20 \mathrm{~nm}$. The spreadability of the SNO was 46 g.cm/sec.

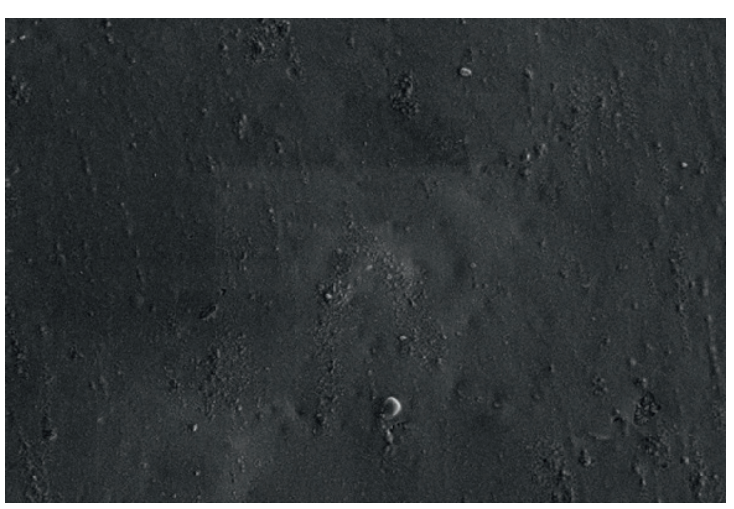

Figure 1. Scanning electron micrograph shows the distribution of silver nanoparticles (SNP) in the ointment. Magnification 10000 KX 
Table 1. Comparison between inhibition of bacterial growth caused by some antibiotics and 3\% SNO used in the study $/ \mathrm{mm}$

\begin{tabular}{lccccccccc}
\hline Antibiotic & Penicillin & Streptomycin & Cefepime & Amoxicillin & Gentamycin & Amikacin & Levofloxacin & Imipenem & $\begin{array}{c}\mathbf{3 \%} \\
\text { SNO }\end{array}$ \\
\hline $\begin{array}{l}\text { Inhibition } \\
\text { zone }\end{array}$ & 0.6 & 0.3 & 1.2 & 0.8 & 1.6 & 1.7 & 1.3 & 2.0 & 9.0 \\
\hline
\end{tabular}

\section{Antimicrobial activity of SNO}

The ointment showed a $9 \mathrm{~mm}$ inhibition zone for the culture of Pseudomonas aeruginosa corresponding to a panel of antibiotics which showed a range of inhibition zone between 0-2 $\mathrm{mm}$ for the same bacteria (Table 1 and Fig. 2).

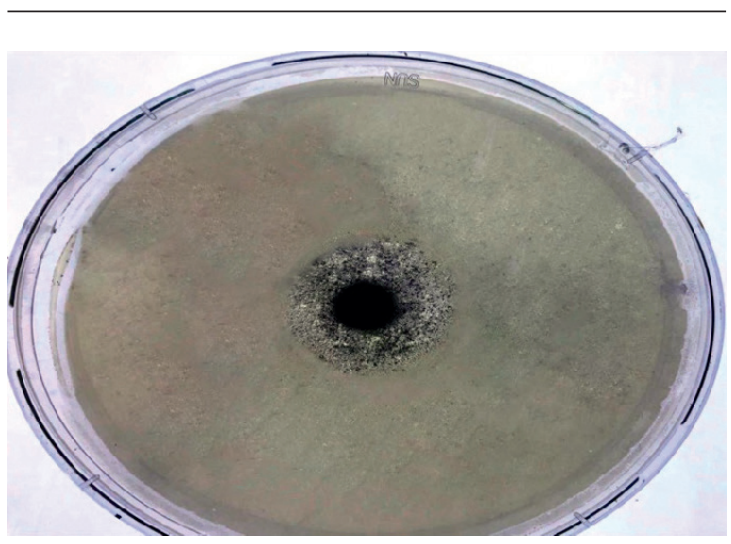

Figure 2. Antibacterial activity of Nano-silver ointment against Pseudomonas aeruginosa

\section{Determination of $L D_{50}$ and infective dose}

The $\mathrm{LD}_{50}$ of Pseudomonas aeruginosa was $10^{9}$ $\mathrm{CFU}$ and the infective dose was $10^{8} \mathrm{CFU}$. The later concentration was used for inducing infection in mice burns.

\section{Animal study}

\section{Gross lesions}

Gross inspection of the positive control revealed skin contraction and debris, 3 days after the burning of the skin. Marked scales were developed on the burned skin on the $7^{\text {th }}$ and $14^{\text {th }}$ day. The average size of the wounds of each subgroup on day 3, 7 and 14 was $1.98 \pm 0.10,1.94 \pm 0.10$, and $1.85 \pm 0.10 \mathrm{~cm}$ respectively.

In the SNO-treated group, scales were formed on day 3, but have sloughed off on day 7. The healing of the skin was almost completed by the $14^{\text {th }}$ day, morphologically being similar to the skin in mice from the negative control group. Remarkable contraction of the burned skin was noticed in this group of mice which was $1.91 \pm 0.20 \mathrm{~cm}$, $1.80 \pm 0.10 \mathrm{~cm}$, and $1.50 \pm 0.30 \mathrm{~cm}$ on days 3,7 and 14 , respectively. The positive control group showed a limited contraction in the burned skin (Table 2 and Fig. 3).

\section{Histopathology}

Histological evaluation of the skin in the negative control group showed normal skin appearance where the epidermal layer contained stratified squamous keratinized epithelium and the adnexa in the dermal layer showed normal components (Fig. 4).

Table 2. Measurement of the burned skin in different periods of the study

\begin{tabular}{lccccc}
\hline Day of measurement & $\begin{array}{c}\text { Number of animals per } \\
\text { group }\end{array}$ & Positive control group/cm & \multicolumn{2}{c}{ Treated group/cm } \\
\hline Day 3 & $\mathrm{n}=4$ & $1.98 \pm 0.10$ & A-a & $1.91 \pm 0.20$ & B-a \\
Day 7 & $\mathrm{n}=4$ & $1.94 \pm 0.10$ & B-a & $1.80 \pm 0.10$ & C-b \\
Day 10 & $\mathrm{n}=4$ & $1.85 \pm 0.10$ & C-b & $1.50 \pm 0.30$ & D-c \\
\hline
\end{tabular}

Values are expressed as mean $\pm \mathrm{SE}$

Capital letters represent significant differences $(\mathrm{p} \leq 0.05)$ within the rows

Small letters represent significant differences $(\mathrm{p} \leq 0.05)$ within the columns 

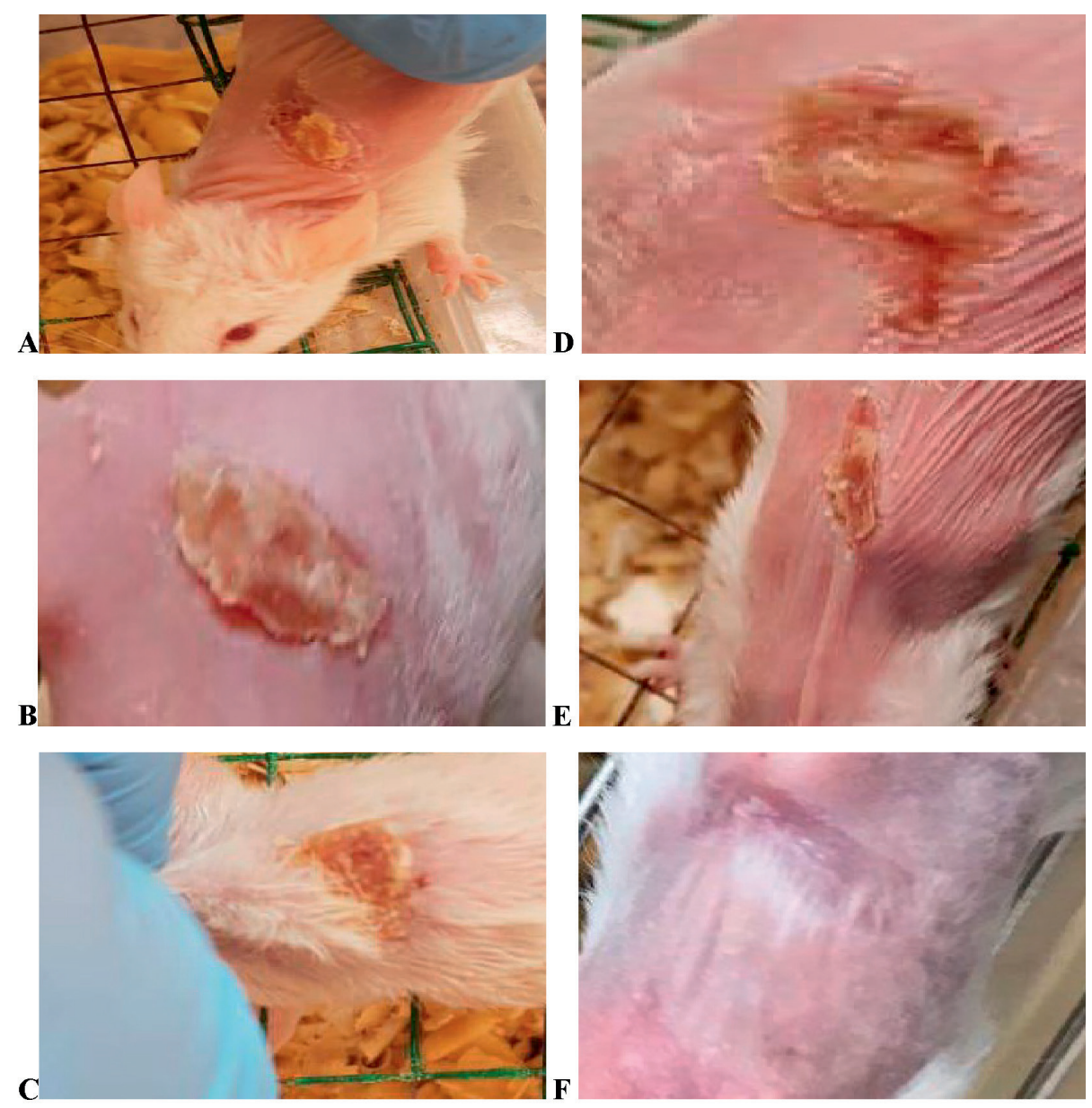

Figure 3. Gross appearance of the burned skin in the positive control group with tissue debris throughout the experimental period: after 3 days (A); after 7 days (B); after 14 days (C). Treated group after 3 days (D); treated group after 7 days (E); treated group after 14 days (F)

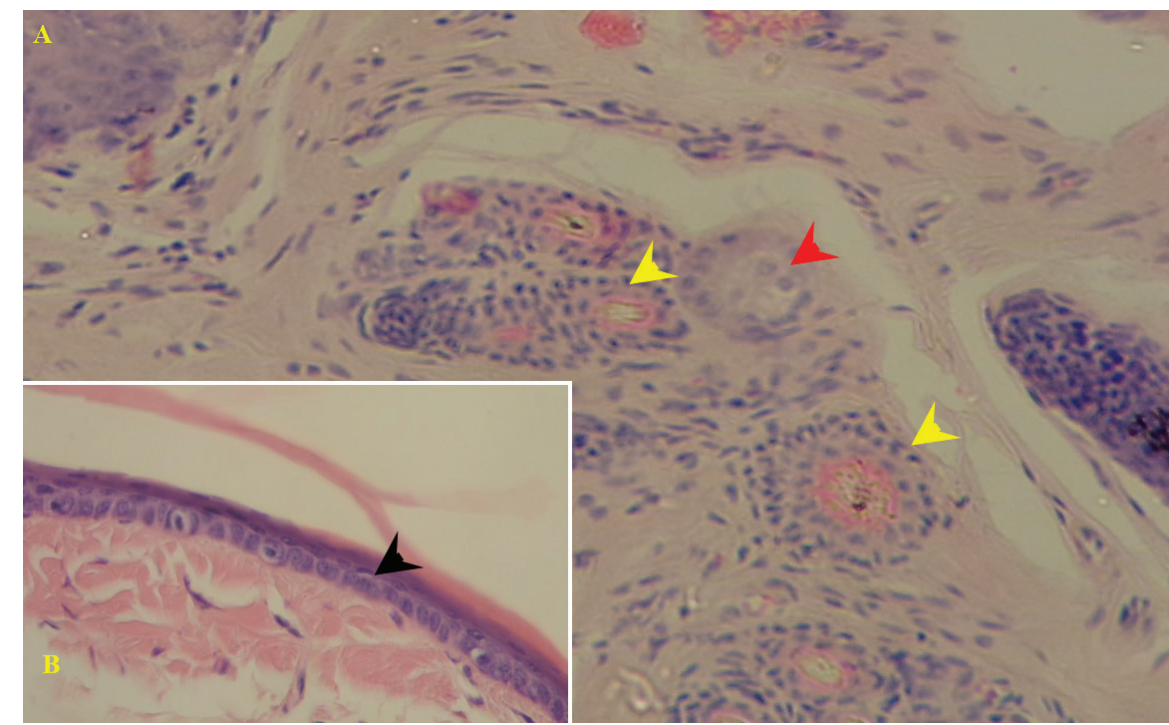

Figure 4. Histological features of skin in control group revealed normal epithelium in the epidermal layer (black arrow head) and normal hair follicle (yellow arrow head) and sebaceous gland (red arrow head) in the dermal layer. H\&E; x125 (A), x500 (B) 
In both, the positive and SNO-treated groups, SNO-treated groups showed similar changes with the entire thickness of the skin was affected. alterations in the epidermal and adnexal layers. After three days, both the positive control and (Fig. 5, 6).

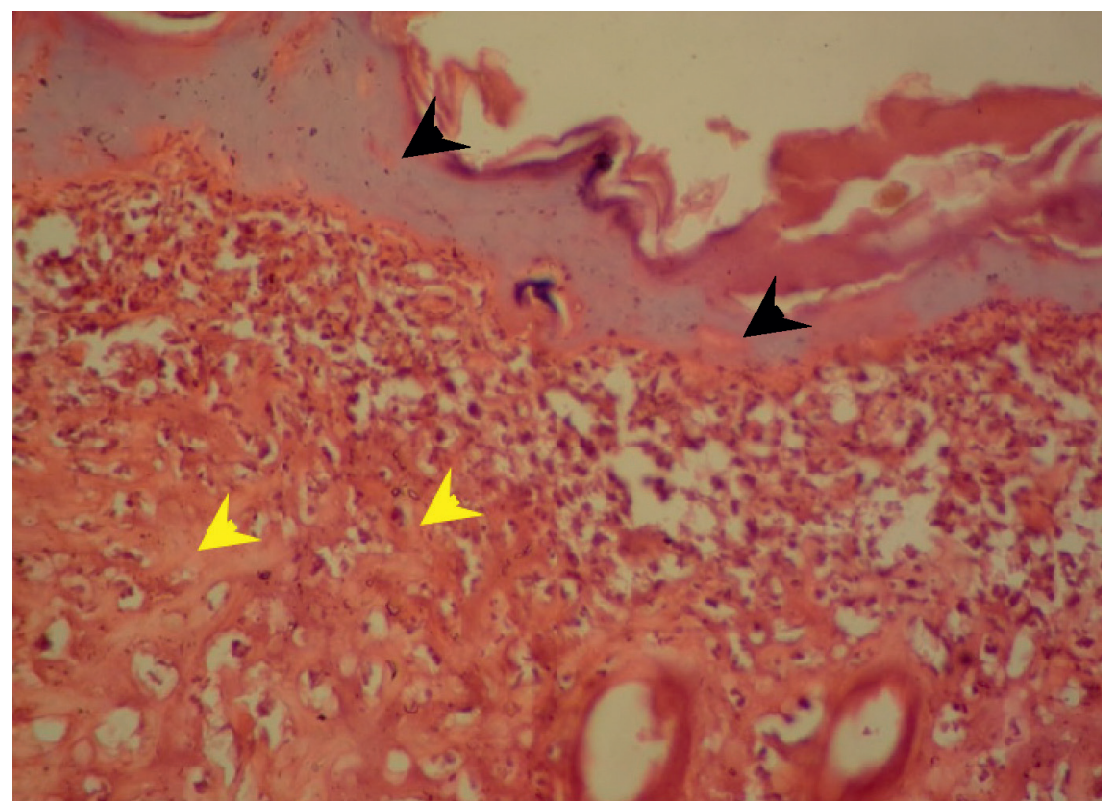

Figure 5. Histopathological features of burned skin for the positive control group after 3 days, reveal necrotized epithelial cells of the epidermal layer (black arrow head), denaturation of the collagen in the dermal layer (yellow arrow head). H\&E; x125

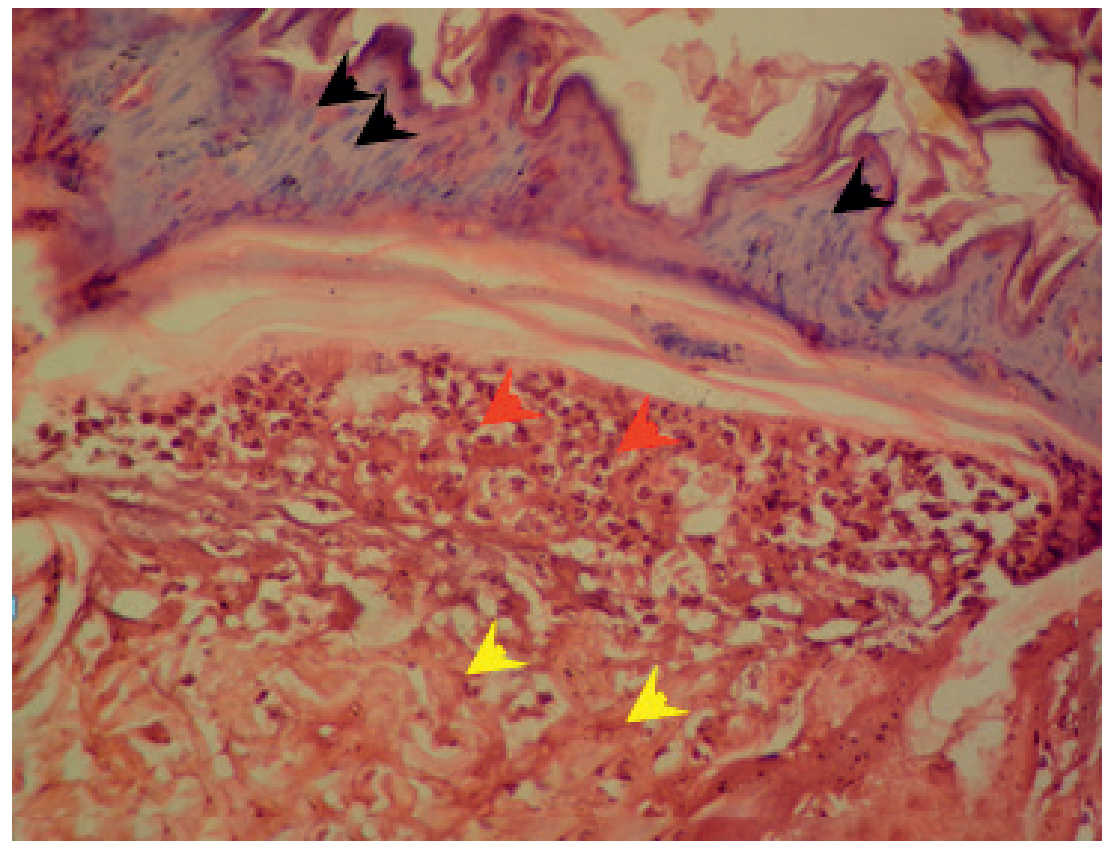

Figure 6. Skin section from SNO-treated group after 3 days of burning reveal necrotized epithelial cells of the epidermal layer (black arrow head), denaturation of the collagen in the dermal layer (yellow arrow head) and neutrophilic infiltration subepidermally (red arrow head). H\&E; x125 
On the $7^{\text {th }}$ day, the positive control group showed the accumulation of tissue debris in the site of the burn with an accumulation of inflammatory cells in the dermo-epidermal junction (Fig. 7). These changes continued until the end of the experiment with slight epithelial regeneration in the epidermis and multiple abscesses in the dermal layer on the $14^{\text {th }}$ day of the experiment (Fig. 9).

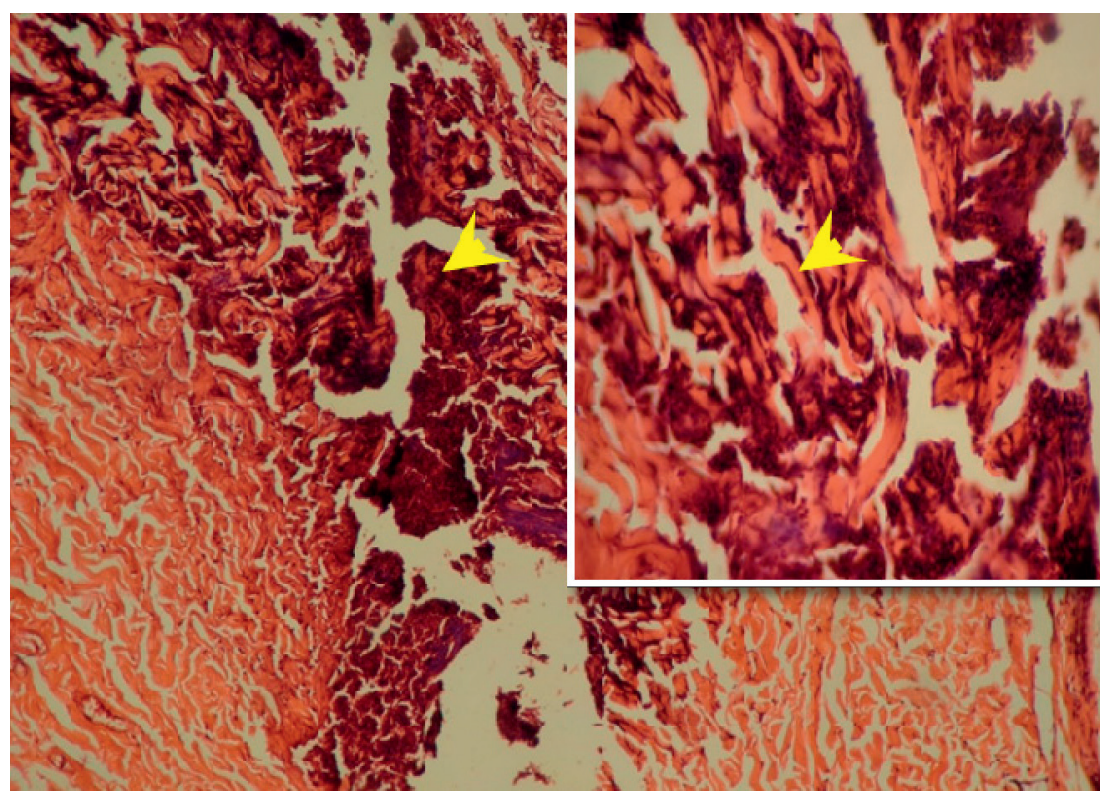

Figure 7. Skin section of the positive control group after 7 days of burning shows tissue debris and denatured collagen (yellow arrow head). H\&E; x125 (A), x500 (B)

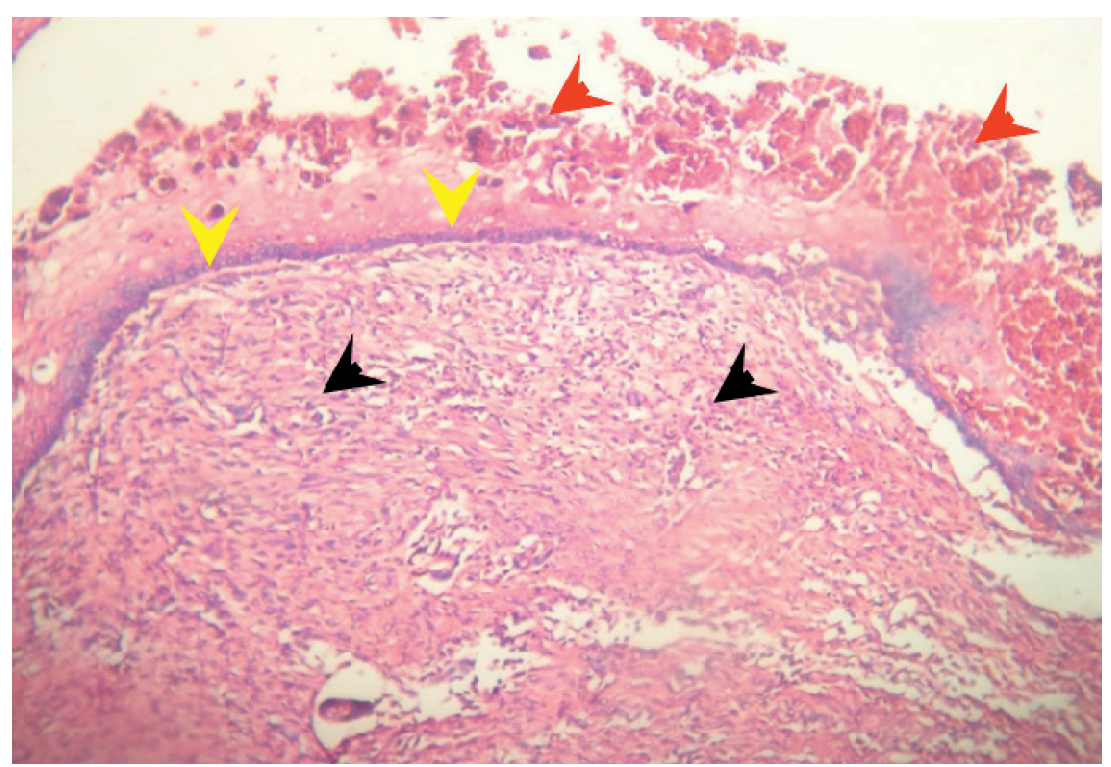

Figure 8. Skin section from SNO-treated group after 7 days of burning reveals tissue debris in the superficial part of the skin (red arrow head), thin layer of newly formed epithelium beneath the debris (yellow arrow head), dense granulation tissue in the dermal layer (black arrow head). H\&E; x125 
In the SNO-treated group, after 7 days there was a reduction of the inflammatory infiltrate and marked epithelial regeneration bridging the burned site beneath the debris with the remodeling tissue in the dermal layer (Fig. 8). On the $14^{\text {th }}$ day, restoration of the full thickness of the epidermis was evident in addition to the marked remodeling of the collagen in the dermal layer with no hair follicles and sebaceous glands, and mild dermal scarring (Fig. 10).

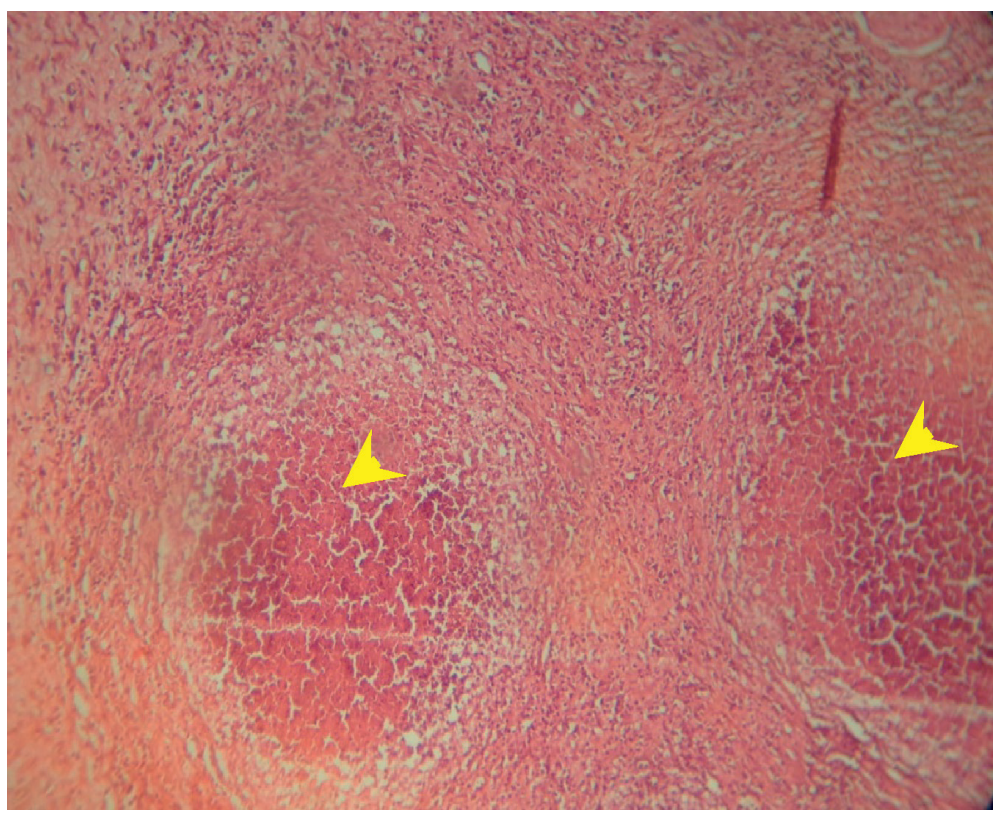

Figure 9. Skin section of the positive control group after 14 days of experiment reveals abscess formation in the dermal layer (yellow arrow head). H\&E; x125

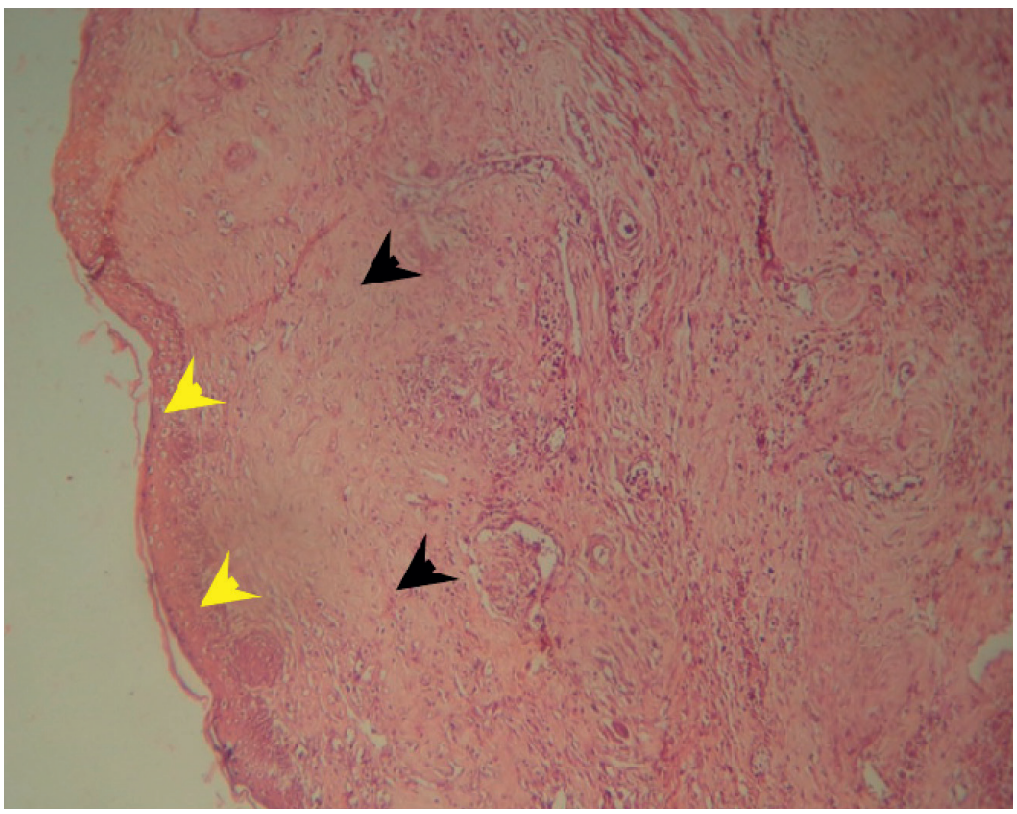

Figure 10. Skin section from SNO-treated group after 14 days of burning reveals complete epithelial regeneration of epidermal layer (yellow arrow head) and mature collagen in the dermal layer (black arrow head). H\&E; x125 


\section{DISCUSSION}

Homogeneity and spreadability of the particles in the ointment were observed to ensure the pharmaceutical suitability of the product. The $\mathrm{pH}$ of the formulation was 6.8 which indicated good compatibility with skin. The results of the visual inspection for homogeneity of the material confirmed no lumps. The ointment homogeneity is important for proper application of the material to ensure even distribution on the affected area (23).

Spreadability denotes the extent of the area to which the prepared formulations readily spread (25). In the current study, the 3\% SNO reported $46 \mathrm{~g} . \mathrm{cm} / \mathrm{sec}$ spreadability, which is negative correlation with the concentration and consistency of the gel (24). Several factors affect the spreadability of each topical formula: 1) firmness, 2) shearing time, 3) affected site temperature, 4) viscosity, 5) evaporation rate of the vehicle and 6) active ingredient concentration that may also affect viscosity (31). In the present study, the spreadability of the ointment was tested before its use to ensure appropriate application. The increasing of SNP concentration from 3-5\% leads to adverse effects on application due to higher viscosity, whereas concentrations in the range of $1-3 \%$ is considered as appropriate (32).

The 3\% SNO which was used in this study showed marked inhibition zone in the agar media in comparison to various antibiotics which have been used in the medium. This is inconsistent with the other study which reported that silver interferes with bacterial cell wall and membrane of bacteria, and inhibits the respiration process (33). Bacterial respiration is responsible for the release and capturing of chemical energy in the form of adenosine triphosphate. It is thought that the replication of the bacteria may be inhibited by SNP by various mechanisms, including bacterial DNA and membrane destruction through interaction with phosphorus-containing compounds and sulfurcontaining proteins, respectively (34).

The current study revealed obvious elimination of the infection in the SNO-treated group. It is known that the phosphomannose isomerase is inactivated by silver. This particular enzyme converts the mannose-6-phosphate to fructose-6-phosphate, the latter being an important intermediate during the glycolysis. This represents the most common pathway in bacteria for sugar catabolism (35). It has been confirmed that SNPs derived free radicals kill the microbes by inhibiting their growth and lowering its infectivity (33).
The effect of $3 \%$ SNO in the treated mice from the experimental group was significantly different than the positive control group. The present study has showed improvement in the healing process that appeared on the third day after inflicting burns. At the end of the experiment, there was complete healing with marked regeneration of the epithelial layer in the epidermis of the skin, compared to the positive control group which showed augmentation in the inflammatory process and development of an abscess in the dermal layer. This may be related to the anti-inflammatory and antimicrobial activity of the silver that play an important role in the suppression of the bacterial load and the inflammatory response in the wound, hence lowering the tissue damage and stimulating the healing process. These findings are in agreement with another report that noted initial healing between the $2^{\text {nd }}$ and the $7^{\text {th }}$ day of the experiment with its peak effect on the $14^{\text {th }}$ day in the treated animals (36).

The anti-inflammatory activity of NSP was observed in both in vivo and in vitro experiments. The wound healing process includes the macrophages which play a vital role in the phagocytic ability, clearing the necrotic tissue, pathogenic microorganisms, and foreign matter. They can also secrete various cytokines and chemokines to stimulate cell proliferation and collagen deposition, promoting vascularization and granulation (37).

In a standard wound healing pattern, the activation of macrophages in non-healing or infected wounds results in higher inflammatory response. Therefore, modulating the macrophage activation in such an instance would aid the healing process. It was clear in this study that there was no augmentation of the inflammatory state in the SNO-treated group. This suggests that NSPs have anti-inflammatory activity by regulating macrophage activity and inflammatory phase progression (38).

SNPs are reported to inhibit the production of proinflammatory cytokines (39) which is in agreement with the findings of the current study. A preliminary study also indicated that keratinocytes and fibroblasts produce growth factors (e.g., VEGF) (40) and proinflammatory cytokines (e.g., IL-8, IL-6, IL-12 and TNF- $\alpha$ ) that subserve inflammatory and immunological reactions to irritants. The SNPs may affect endothelial cells expression of the VEGF, which plays an important role in some pathological conditions, such as abnormal wound healing (41). 


\section{CONCLUSION}

The present study showed that SNO provided a good formula to treat skin burns through its antibacterial and anti-inflammatory activity, stimulating keratinocyte and fibroblast proliferation, enhancing collagen deposition. One of the limitations in the work was the small number of experimental animals for the various trials which included different dosages of SNO. Further investigations with larger animal number should be conveyed to additionally validate these findings.

\section{CONFLICT OF INTEREST}

The authors declare that there is no conflict of interest related to this article.

\section{ACKNOWLEDGEMENTS}

The authors would like to thank Assistant Prof. Dr. Mysaa Ghzi Jumaa the head of Department of microbiology for her support in accomplishing part of the work in the Microbiology laboratory, Medical college, University of Misan. Thanks also for Dr. Moammed Madi for his scientific advices regarding the bacteriological aspects of the research.

\section{AUTHORS' CONTRIBUTIONS}

MAR performed the laboratory animals experiment and the pathological study, ANB supplied the instruments and equipment's of the experiment, review and language editing of the manuscript. SBK provided the bacterial strain and accomplish the microbiological study of the study. HFA provided the pharmacological information and advices as well as calculation of the ratio of the contents of the $3 \% \mathrm{SNO}$.

\section{REFERENCES}

1. Zhou, E.H., Watson, C., Pizzo, R., Cohen, J., Dang, Q., Ferreira de Barros, P.M., Park, C.Y., et al. (2014). Assessing the impact of engineered nanoparticles on wound healing using a novel in vitro bioassay. Nanomedicine (Lond.). 9(18): 2803-2815.

https://doi.org/10.2217/nnm.14.40

PMid:24823434 PMCid:PMC4684260
2. McLaughlin, S., Podrebarac, J., Ruel, M., Suuronen, E.J., McNeill, B., Alarcon, E.I. (2016). Nano-engineered biomaterials for tissue regeneration: what has been achieved so far? Front Mater. 3, 27. https://doi.org/10.3389/fmats.2016.00027

3. Jain, J., Arora, S., Rajwade, J.M., Omray, P., Khandelwal, S., Paknikar, K.M. (2009). Silver nanoparticles in therapeutics: development of an antimicrobial gel formulation for topical use. Mol Pharm. 6(5): 1388-1401. https://doi.org/10.1021/mp900056g PMid:19473014

4. Rigo, C., Ferroni, L., Tocco, I., Roman, M., Munivrana, I., Gardin, C., Cairns, W.R., et al. (2013). Active silver nanoparticles for wound healing. Int $\mathrm{J}$ Mol Sci. 14(3): 4817-4840.

https://doi.org/10.3390/ijms14034817

PMid:23455461 PMCid:PMC3634485

5. Klasen, H.J. (2000). A historical review of the use of silver in the treatment of burns. II. Renewed interest for silver. Burns 26(2): 131-138. https://doi.org/10.1016/S0305-4179(99)00116-3

6. Klasen, H.J. (2000). Historical review of the use of silver in the treatment of burns. I. Early uses. Burns 26(2): 117-130. https://doi.org/10.1016/S0305-4179(99)00108-4

7. Hussain, S., Ferguson, C. (2006). Best evidence topic report. Silver sulphadiazine cream in burns. Emerg Med J. 23(12): 929-932. https://doi.org/10.1136/emj.2006.043059 PMid:17130603 PMCid:PMC2564257

8. Okan, D., Woo, K., Sibbald, R.G. (2007). So what if you are blue? Oral colloidal silver and argyria are out: safe dressings are in. Adv Skin Wound Care. 20(6): 326-330.

https://doi.org/10.1097/01.ASW.0000276415.91750.0f PMid:17538258

9. Cutting, K., White, R., Edmonds, M. (2007). The safety and efficacy of dressings with silver - addressing clinical concerns. Int Wound J. 4(2): 177-184. https://doi.org/10.1111/j.1742-481X.2007.00338.x PMid:17651232

10. Fong, J., Wood, F. (2006). Nanocrystalline silver dressings in wound management: a review. Int $\mathrm{J}$ Nanomedicine. 1(4): 441-449. https://doi.org/10.2147/nano.2006.1.4.441 PMid:17722278 PMCid:PMC2676636

11. Burd, A., Kwok, C.H., Hung, S.C., Chan, H.S., Gu, H., Lam, W.K., Huang, L. (2007). A comparative study of the cytotoxicity of silver-based dressings in monolayer cells, tissue explants, and animal models. Wound Repair Regen. 15(1): 94-104. https://doi.org/10.1111/j.1524-475X.2006.00190.x PMid:17244325 
Effect of silver nanoparticles on third-degree burn healing

12. Tegos, G.P., Demidova, T.N., Arcila-Lopez, D., Lee, H., Wharton, T., Gali, H., Hamblin, M.R. (2005). Cationic fullerenes are effective and selective antimicrobial photosensitizers. Chem Biol. 12(10): 1127-1135.

https://doi.org/10.1016/j.chembiol.2005.08.014

PMid:16242655 PMCid:PMC3071678

13. Robins, E.V. (1990). Burn shock. Crit Care Nurs Clin North Am. 2(2): 299-307.

https://doi.org/10.1016/S0899-5885(18)30830-X

14. Dai, T., Huang, Y.Y., Sharma, S.K., Hashmi, J.T., Kurup, D.B., Hamblin, M.R. (2010). Topical antimicrobials for burn wound infections. Recent Pat Antiinfect Drug Discov. 5(2): 124-151.

https://doi.org/10.2174/157489110791233522

PMid:20429870 PMCid:PMC2935806

15. Hendi, A. (2011). Silver nanoparticles mediate differential responses in some of liver and kidney functions during skin wound healing. J King Saud Uni. 23(1): 47-52.

https://doi.org/10.1016/j.jksus.2010.06.006

16. Cordeiro, M.F. (2002). Beyond mitomycin: TGFbeta and wound healing. Prog Retin Eye Res. 21(1): $75-89$.

https://doi.org/10.1016/S1350-9462(01)00021-0

17. Adhya, A., Bain, J., Ray, O., Hazra, A., Adhikari, S., Dutta, G., Ray, S., Majumdar, B.K. (2014). Healing of burn wounds by topical treatment: A randomized controlled comparison between silver sulfadiazine and nano-crystalline silver. J Basic Clin Pharm. 6(1): 29-34.

https://doi.org/10.4103/0976-0105.145776

PMid:25538469 PMCid:PMC4268627

18. Tian, J., Wong, K.K., Ho, C.M., Lok, C.N., Yu, W.Y., Che, C.M., Chiu, J.F., Tam, P.K. (2007). Topical delivery of silver nanoparticles promotes wound healing. Chem Med Chem. 2(1): 129-136.

https://doi.org/10.1002/cmdc.200600171

PMid:17075952

19. Sibbald, R.G., Contreras-Ruiz, J., Coutts, P., Fierheller, M., Rothman, A., Woo, K. (2007). Bacteriology, inflammation, and healing: a study of nanocrystalline silver dressings in chronic venous leg ulcers. Adv Skin Wound Care. 20(10): 549-558. https://doi.org/10.1097/01.ASW.0000294757.05049.85 PMid:17906429

20. Nadworny, P.L., Wang, J., Tredget, E.E., Burrell, R.E. (2008). Anti-inflammatory activity of nanocrystalline silver in a porcine contact dermatitis model. Nanomedicine. 4(3): 241-251.

https://doi.org/10.1016/j.nano.2008.04.006

PMid:18550449
21. Wright, J.B., Lam, K., Buret, A.G., Olson, M.E., Burrell, R.E. (2002). Early healing events in a porcine model of contaminated wounds: effects of nanocrystalline silver on matrix metalloproteinases, cell apoptosis and healing. Wound Rep Regen. 10, 141-151. https://doi.org/10.1046/j.1524-475X.2002.10308.x PMid:12100375

22. Huang, Y., Li, X., Liao, Z., Zhang, G., Liu, Q., Tang, J., Peng, Y., Liu, X., Luo, Q. (2007). A randomized comparative trial between Acticoat and SD-Ag in the treatment of residual burn wounds, including safety analysis. Burns 33(2): 161-166. https://doi.org/10.1016/j.burns.2006.06.020 PMid:17175106

23. Saha, A., Kumar Giri, N., Agarwal, S.P. (2017). Silver nanoparticle-based hydrogels of tulsi extracts for topical drug delivery. Int J Ayurveda Pharma Res. 5(1): 17-23.

24. Dandasi, J.D., Jayaprakash, J.S., Kulkarni, P.K., Akhila, A.R., Namratha, S.S. (2020). Formulation and evaluation of different topical dosage forms for wound healing properties. Int J Pharm Sci Res. 1, 10-23.

25. Patel, J., Patel, B., Banwait, H., Parmar, K., Patel, M. (2011). Formulation and evaluation of topical Aceclofenac gel using different gelling agents. Int J Drug Dev \& Res. 3(1): 156-164.

26. Mayr-Harting, A., Hedges, A., Berkeley, R. (1972). Methods for studying bactericides. In: Norris, J. R., Ribbons, D.W. (Eds.), Methods in Microbiology. Vol. 7A (p. 74). New York: Academic Press. https://doi.org/10.1016/S0580-9517(08)70618-4

27. Tymen, S.D., Rojas, I.G, Zhou, X., Fang, Z.J., Zhao, Y., Marucha, P.T. (2013). Restraint stress alters neutrophil and macrophage phenotypes during wound healing. Brain Behav Immun. 28, 207-217. https://doi.org/10.1016/j.bbi.2012.07.013 PMid:22884902 PMCid:PMC3878450

28. Crichton, M.L., Chen, X., Huang, H., Kendall, M.A. (2013). Elastic modulus and viscoelastic properties of full-thickness skin characterized at micro scales. Biomaterials 34(8): 2087-2097.

https://doi.org/10.1016/j.biomaterials.2012.11.035 PMid:23261214

29. Reed, L.J., Muench, H. (1938). A simple method of estimating fifty percent endpoints. Am J Hyg. 27(3): 493-497.

https://doi.org/10.1093/oxfordjournals.aje.a118408

30. Adedapo, A., Babarinsa, O., Oyagbemi, A., Adedapo, A., Omobowale, T. (2016). Cardiotoxicity study of the aqueous extract of corn silk in rats. Mac Vet Rev. 39 (1): 43-49. https://doi.org/10.1515/macvetrev-2015-0065 
31. Rance, R.W. (1973). Studies of the factors controlling the action of hair sprays-I: the spreading of hair spray resin solutions on hair. J Soc Cosmet Chem. 24, 501-522.

32. Jones, D.S., Woolfson, A.D., Brown, A.F. (1997). Texture analysis and flow rheometry of novel, bioadhesive antimicrobial oral gels. Pharm Res. 14(4): 450-457.

https://doi.org/10.1023/A:1012091231023

PMid:9144730

33. Slistan-Grijalva, A., Herrera-Urbina, R., Rivas-Silva, J.F., Avalos-Borja, M., Castillon-Barraza, F.F., Posada-Amarillas, A. (2005). Classical theoretical characterization of the surface plasmon absorption band for silver spherical nanoparticles suspended in water and ethylene glycol. Physica E. 27, 104-112. https://doi.org/10.1016/j.physe.2004.10.014

34. Shrivastava, S., Bera, T., Roy, A., Singh, G., Ramachandrarao, P., Dash, D. (2007). Characterization of enhanced antibacterial effects of novel silver nanoparticles. Nanotechnology 18, 103-112.

https://doi.org/10.1088/0957-4484/18/22/225103

35. Litvin, V.A., Minaev, B.F. (2013). Spectroscopy study of silver nanoparticles fabrication using synthetic humic substances and their antimicrobial activity. Spectrochim Acta A Mol Biomol Spectrosc. 108, 115-122.

https://doi.org/10.1016/j.saa.2013.01.049 PMid:23466321

36. Heydarnejad, M.S., Rahnama, S., Mobini-Dehkordi, M., Yarmohammadi, P., Aslnai, H. (2014). Silver nanoparticles accelerate skin wound healing in mice (Mus musculus) through suppression of the innate immune system. Nanomed J. 1(2): 79-87.
37. You, C., Li, Q., Wang, X., Wu, P., Ho, J.K., Jin, R., Zhang, L., Shao, H., Han, C. (2017). Silver nanoparticle loaded collagen/chitosan scaffolds promote wound healing via regulating fibroblast migration and macrophage activation. Sci Rep. 7(1): 1-11. https://doi.org/10.1038/s41598-017-10481-0 PMid:28874692 PMCid:PMC5585259

38. Chanan-Khan, A., Szebeni, J., Savay, S., Liebes, L., Rafique, N.M., Alving, C.R., Muggia F.M. (2003). Complement activation following first exposure to pegylated liposomal doxorubicin (Doxil): possible role in hypersensitivity reactions. Ann Oncol. 14(9): 1430-1437.

https://doi.org/10.1093/annonc/mdg374

PMid:12954584

39. Zhang, S., Liu, X., Wang, H., Peng, J., Wong, K.K. (2014). Silver nanoparticle-coated suture effectively reduces inflammation and improves mechanical strength at intestinal anastomosis in mice. J Pediatr Surg. 49(4): 606-613.

https://doi.org/10.1016/j.jpedsurg.2013.12.012

PMid:24726122

40. Gohel, M.S., Windhaber, R.A., Tarton, J.F., Whyman, M.R., Poskitt, K.R. (2008). The relationship between cytokine concentrations and wound healing in chronic venous ulceration. J Vasc Surg. 48(5): 1272-1277.

https://doi.org/10.1016/j.jvs.2008.06.042

PMid:18771884

41. Franková, J., Pivodová, V., Vágnerová, H., Juráňová, J., Ulrichová, J. (2016). Effects of silver nanoparticles on primary cell cultures of fibroblasts and keratinocytes in a wound-healing model. J Appl Biomater Funct Mater. 14(2): e137-142. https://doi.org/10.5301/jabfm.5000268 PMid:26952588 